\title{
Therapeutic Challenges in Systemic Lupus Erythematosus Patient with Pregnancy, Osteoporosis, and Severe Thrombocytopenia: A Case Report and Review of Literature
}

\section{Tantangan Terapi pada Pasien Lupus Eritematosus Sistemik dengan Kehamilan, Osteoporosis, dan Trombositopenia Berat: Sebuah Laporan Kasus dan Tinjauan Literatur}

\author{
Yosefin Ratnaningtyas, Perdana Aditya $R$
}

Department of Internal Medicine Faculty of Medicine Universitas Brawijaya Malang

\begin{abstract}
Systemic Lupus Erythematosus (SLE) is a complex autoimmune disease that requires long-term corticosteroid treatment that may lead to osteoporosis characterized by low bone mass and microarchitectural deterioration of the trabecular and cortical skeletal. This study presents a severe case of thrombocytopenia in a 25-year old woman with SLE and osteoporosis who underwent routine therapy and was pregnant for the first time. The complexity of pregnancy and autoimmune conditions create therapeutic challenges that need to be considered in SLE patients with pregnancy, osteoporosis, and severe thrombocytopenia.
\end{abstract}

Keywords: Osteoporosis, pregnancy, systemic lupus erythematosus, thrombocytopenia

\section{ABSTRAK}

Lupus Eritematosus Sistemik (LES) adalah penyakit autoimun kompleks yang membutuhkan pengobatan kortikosteroid jangka panjang yang dapat menyebabkan osteoporosis ditandai dengan penurunan massa tulang dan perubahan mikroarsitektur trabekuler dan kortikal tulang. Kajian ini melaporkan kasus trombositopenia berat pada wanita berusia 25 tahun dengan LES dan osteoporosis yang menjalani terapi rutin dan mengalami kehamilan pertama. Kompleksitas kehamilan dan kondisi autoimun menimbulkan tantangan terapeutik yang perlu dipertimbangkan pada pasien LES dengan kehamilan, osteoporosis, dan trombositopenia berat.

Kata Kunci: Kehamilan, lupus eritematosus sistemik, osteoporosis, trombositopenia

Correspondence: Yosefin Ratnaningtyas. Department of Internal Medicine Faculty of Medicine Universitas Brawijaya Malang, Jl. Jaksa Agung Suprapto No.2, Klojen, Kec. Klojen, Kota Malang, Jawa Timur65111 Tel. 082221834862 Email: yosefinratnaningtyas@gmail.com

DOI: http://dx.doi.org/10.21776/ub.jkb.2021.031.03.6 


\section{INTRODUCTION}

Systemic Lupus Erythematosus (SLE) is a complex autoimmune disease that attacks various body systems. The condition is characterized by the formation of pathogenic autoantibodies against nucleic acids and their binding proteins due to intolerance to the body's components. Thrombocytopenia is one of the primary manifestations of ITP in SLE found in $10.9-17.9 \%$ of SLE patients. ITP first-line therapy is high-dose corticosteroids that can increase the risk of osteoporosis in SLE patients. The long-term use of corticosteroids in SLE treatment is a specific risk factor for osteoporosis in SLE. Ten percent of patients who received long-term corticosteroid treatment are diagnosed as osteoporosis. The use of drugs in SLE patients also needs to be considered during conception, pregnancy, lactation, and perioperative periods since in the final trimester of pregnancy calcium mobilization and bone resorption will increase. These changes could cause osteoporosis and fractures in pregnant women $(1,2)$. This study reported a Systemic Lupus Erythematosus patient with Primigravida who experienced Osteoporosis and Severe Thrombocytopenia with a focus on osteoporosis therapy in pregnancy.

\section{CASE REPORT}

A 25-year-old woman came to the Rheumatology Outpatient Clinic of Dr. Saiful Anwar Hospital (RSSA) with the chief complaint of gum bleeding for the past one week. Bleeding occurs when brushing teeth stop within minutes. There were no other bleeding complaints. The patient has been diagnosed with Systemic Lupus Erythematosus (SLE) in the past five years with manifestations of a low level of platelets and lymphocytes accompanied by joint pain, hair loss, oral ulcers, with positive ANA test result. The patient routinely underwent periodic examinations and obtained a therapy of chloroquine $1 \times 250 \mathrm{mg}$, methylprednisolone at reduced doses, calcium lactate $2 \times 500 \mathrm{mg}$, and mycophenolate sodium $2 \times 180 \mathrm{mg}$.

The patient was diagnosed with osteoporosis when she was 23 years old through BMD examination and underwent treatment with risedronate $35 \mathrm{mg} /$ week for the past 1.5 years. The patient knew her pregnancy three weeks before a visit to the hospital with a gestational age of 12-14 weeks. Since knowing the pregnancy, the patient stopped taking sodium mycophenolate and risedronate and then experiences gum bleeding, which was the patient's main complaint on the hospital visit. The last drugs consumed were $4 \mathrm{mg}$ methylprednisolone every two days, risedronate $35 \mathrm{mg}$ once a week, mycophenolate sodium 2x180 mg, and calcium lactate $2 \times 500 \mathrm{mg}$.

This pregnancy was her first pregnancy, and the first day of the last menstrual period (LMP) was September $15^{\text {th }}$, 2019; thus, the estimated delivery date was June $22^{\text {nd }}$, 2020. The patient has undergone two antenatal care examinations (ANC) to the midwife. The patient had a history of hospitalization because of very low platelet levels when she was first diagnosed with SLE. There is no history of lupus, bone fractures, or blood disorders in the family. The patient is a housewife and lives with her sister and her husband, who works as a street vendor.

Physical examination results showed that the patient had a good consciousness, $120 / 80 \mathrm{mmHg}$ blood pressure, $120 \mathrm{x} / \mathrm{min}$ pulse rate, $21 \mathrm{x} / \mathrm{min}$ respiration rate, and $36.9^{\circ} \mathrm{C}$ axillary temperature. There was ablood clot without active bleeding on the left lower jaw. The results of the abdominal examination found that the stomach was flat gravid with normal bowel sounds, and the uterus was felt in 1 finger above the symphysis. Physical examination also revealed Petechia in the right and left cruris of the patient.

The bone marrow density (BMD) examination on May $22^{\text {nd }}$, 2019 showed femur neck bone density of $0.609 \mathrm{~g} / \mathrm{cm}^{3}$ (N: 0.74-1) with T score -1.84, and a total bone density of L1-L4 of $0.59 \mathrm{~g} / \mathrm{cm}^{3}$ (N: 0.85-1.1) with T score -2.94. The BMD picture of the pelvis showed a $2.8 \%$ increase compared to the BMD results on May $11^{\text {th }}, 2018$, with a conclusion of osteoporosis and a high risk of hip fracture (>3\%). The patient had been advised to repeat the BMD examination annually for therapy evaluation. Laboratory examination on December $10^{\text {th, }} 2019$ showed thrombocytopenia $(15,000 / \mathrm{uL})$ with a $13 \%$ increase in immature platelet fraction (IPF) and Vitamin D 25-OH deficiency at $9.2 \mathrm{ng} / \mathrm{ml}$ $(<12)$.

The diagnosis determined for the patient was Systemic Lupus Erythematosus with manifestations of severe thrombocytopenia, G1P0A0, 12-14 weeks gestational age, with osteoporosis, and vitamin $D$ deficiency.

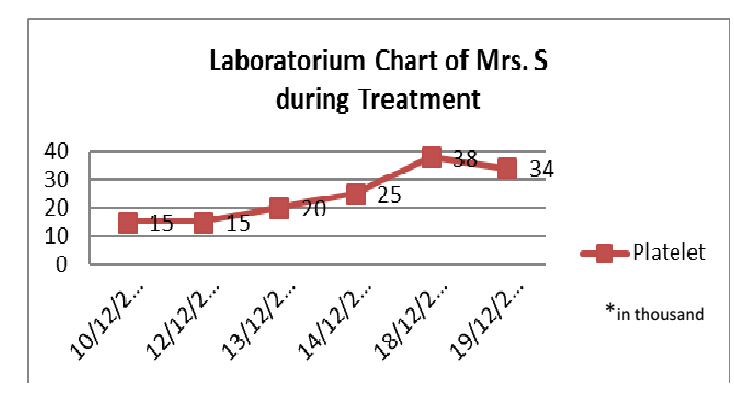

Figure 1. Laboratory chart during treatment

Note: Laboratory chart demonstrated improvement in platelet values during treatment

Intravenous therapy given was Methylprednisolone $2 \times 62.5 \mathrm{mg}$ for five days and administration of normal fluid saline $1500 \mathrm{cc} / 24$ hours, TC transfusion 1 pack/24 hours to avoid alloimmunization. The oral administrations were folic acid 1x1 mg, CaCO3 2x500 mg, Azathioprine 2x50 mg and cholecalciferol $3 \times 400$ iu as adjunctive therapy for osteoporosis. The patient must undergo nonpharmacological therapy, including bed rest on a highcalorie, high-protein diet. The Obstetrics and Gynecology Division monitored antenatal care with conservative care. The patient underwent clinical and laboratory improvement during the treatment (Figure 1), resulted in stable hemodynamics with no signs of re-bleeding during the treatment.

After the treatment at the hospital, patients underwent regular periodic examinations at the Rheumatology clinic. The continued treatment included Methylprednisolone $3 \times 16 \mathrm{mg}$ tapering $4 \mathrm{mg} /$ week, Folic Acid 1x1 mg, CaCO3 2x500 mg, Azathioprine 2x50 mg, and Cholecalciferol $3 \times 400$ iu. During outpatient care, laboratory results showed an increase in platelet count and $25-\mathrm{OH}$ vitamin $\mathrm{D}$ level (Tabel 1), and there were no complaints of bleeding or pain in the bones. The patient delivered a baby girl on June $29^{\text {th }}, 2020$ without complications. Birth weight was 2350 
Tabel 1. Subsequent laboratorium findings

\begin{tabular}{|c|c|c|c|c|c|c|c|}
\hline $\begin{array}{l}\text { Laboratorium } \\
\text { findings }\end{array}$ & $\begin{array}{c}1^{\text {st }} \text { visit } \\
\text { Dec } 2020\end{array}$ & $\begin{array}{c}2^{\text {nd }} \text { visit } \\
\text { Jan } 2020\end{array}$ & $\begin{array}{c}3^{\text {rd }} \text { visit } \\
\text { Feb } 2020\end{array}$ & $\begin{array}{c}4^{\text {th }} \text { visit } \\
\text { March } 2020\end{array}$ & $\begin{array}{c}5^{\text {th }} \text { visit } \\
\text { April } 2020\end{array}$ & $\begin{array}{c}6^{\text {th }} \text { visit } \\
\text { May } 2020\end{array}$ & $\begin{array}{c}7^{\text {th }} \text { visit } \\
\text { June } 2020\end{array}$ \\
\hline $\mathrm{Hb}(\mathrm{g} / \mathrm{dl})$ & 10.8 & 11.1 & 10.4 & 9.9 & 9.3 & 10.7 & 10 \\
\hline WBC (YL) & 10.120 & 6.970 & 5.690 & 4.230 & 4.400 & 5.220 & 6.600 \\
\hline Platelet (YL) & 35.000 & 32.000 & 38.000 & 41.000 & 50.000 & 62.000 & 79.000 \\
\hline PT/APTT (sec) & $11.4 / 31.9$ & & & & & & $9.8 / 26.5$ \\
\hline INR & 1.1 & & & & & & 1 \\
\hline IPF (\%) & 13 & - & - & - & - & & - \\
\hline Vitamin D 25-OH (ng/ml) & 9.2 & - & - & - & - & 22.3 & - \\
\hline IgM Anti Cardiolipin MPL(U/ml) & 2.8 & - & - & - & - & & - \\
\hline \multicolumn{8}{|l|}{ IgG Anti Cardiolipin } \\
\hline $\mathrm{MPL}(\mathrm{U} / \mathrm{ml})$ & 2 & & & & & & \\
\hline
\end{tabular}

Note: Subsequent Laboratorium Findings demonstrated improvement in platelet values and vitamin D

gram, physical examination showed no abnormalities.

\section{DISCUSSION}

This case report found osteoporosis in early pregnancy with vitamin D deficiency in an SLE patient. This condition could increase the risk of pathological fracture in the patient because the last six weeks of pregnancy. The mother will be lost 300-500 mg of calcium per day for the fetal osteogenesis, and approximately $200 \mathrm{mg}$ of calcium is lost each day through breastfeeding, thus affecting calcium metabolism of the mother. During pregnancy and after childbirth, intestinal calcium absorption increases to meet the calcium levels needed in the breast milk. Increased maternal bone resorption can cause fractures in the mother.

Some of the therapeutic approaches chosen in this case were to stop administering risedronate and followed by supplementation of vitamin $D$ and calcium. Various studies have presented therapeutic options for osteoporosis in pregnancy, including bisphosphonates (3). A study by Levy et al., in 21 pregnant women exposed to various types of bisphosphonates, that were alendronate $(n=12)$, etidronate $(n=5)$, risedronate $(n=2)$, and pamidronate $(n=2)$, found no abnormalities in neonates compared to the control group (4). These data were validated by a systematic review of 51 cases of exposure to various types of bisphosphonates before or during pregnancy that did not find cases of bone abnormalities or other congenital abnormalities in neonates. Djokanovic et al., reported in a case series of 24 pregnancies with prepregnancy or early pregnancy exposure to alendronate, and there were 19 live birth infants and five miscarriages. No major congenital anomalies were found (5).

However, the administration of bisphosphonates must be avoided in pregnancy because this drug can pass through the placenta and last long in the bones, so there is a potential risk of exposure to the fetus, especially in unplanned pregnancies. Two major concerns need to be considered regarding bisphosphonate therapy in pregnant women. First, bisphosphonates are category C drugs for fetal safety because data on a mouse model show toxic effects due to the accumulation of bisphosphonates in the fetal skeleton, although many case reports in humans show no adverse effects on the mother or fetus. Secondly, although bisphosphonate therapy in pregnant patients with osteoporosis in the short term can show an improved picture of BMD, the effectiveness in preventing fractures and the long-term risk of bisphosphonate exposure remains unclear $(3,6)$.

There are several studies on osteoporosis treatment in post-partum patients (Appendix 1). Sarikaya et al. (2004) established a significant improvement in BMD measurements of patients treated with Alendronate- $\mathrm{Na}$ $10 \mathrm{mg} /$ day and calcium carbonate $1000 \mathrm{mg} /$ day for six months (7). Research by Allalli et al., Grizzo et al., and Zhang et al., identified a significant increase in BMD of patients given vitamin $\mathrm{D}$ and calcium supplementation (810). Teriparatide, a recombinant human parathyroid hormone 1-34, has been considered a potential therapeutic agent for osteoporosis. Polat et al., and ljuin et al., reported a significant increase in BMD of patients treated with cholecalciferol, calcium, and teriparatide $(11,12)$. Winarno et al., presented a successful treatment of 1-34 parathyroid hormone (PTH) after the failure of bisphosphonate therapy in cases of pregnancy-associated osteoporosis and complex multiple fractures. After 18 months of treatment of PTH1-34, the BMD of the patients improved (13). Despite this, no data are available regarding the risk of congenital disorders, miscarriage, or adverse outcomes in the mother or fetus due to the use of teriparatide in pregnant women. Consideration of discontinuing the drug when pregnancy is known has been suggested even though the use of teriparatide can be used for patients with recurrent fractures or high-risk fractures (5).

Selective estrogen receptor modulators (SERMs) are a group of estrogen receptor agonist/antagonist with tissueselective effects. Raloxifene, lasofoxifene, and basedoxifene have been approved as a treatment for osteoporosis in Europe. Raloxifene is the only SERM currently approved by the US FDA for the prevention and treatment of osteoporosis. Raloxifene significantly decreases bone resorption and turnover, increases BMD $2-3 \%$ in the hip and spine, and decreases vertebral fracture incidence by $30-50 \%$. However, the effect of the drug on pregnancy has not been established by the US FDA. This drug is classified as AU TGA pregnancy category $X$ that means this drug has a high risk of causing permanent damage to the fetus and should not be used in pregnancy or when there is a possibility of pregnancy. Based on the action mechanism, this drug could block the important functions of estrogen at all stages of pregnancy (14).

Romosozumab, a specific inhibitor of sclerostin, is also a new and unique approach to the treatment of postmenopausal osteoporosis and related disorders. The decreased relative risk of vertebral fracture during the 
second year of therapy in the FRAME study showed an $80 \%$ greater reduction in vertebral fracture risk in patients receiving romosozumab followed by denosumab when compared with the placebo group. In the ARCH study, the effects of romosozumab were superior to alendronate therapy that showed a $48 \%$ greater reduction in spinal fractures during the $2^{\text {nd }}$ year of therapy. In the clinical trials, romosozumab has been well-tolerated, but romosozumab is not indicated for use in women who have the potential for pregnancy. In animal studies, weekly administration of romosozumab to pregnant rats during the period of organogenesis showed 32 times greater exposures and resulted in fetal bone abnormalities $(15,16)$.

Pregnancy poses a challenge to the mother's bones because the construction of the fetal skeleton requires substantial calcium transfer. This process is very intense during the third trimester when fetal bones undergo substantial growth and calcification; the mother bears this mechanism, which can produce a degree of damage to the mother's bones unless there is a sufficient compensation mechanism from the mother. If an adequate balance is not achieved, pregnancy will increase susceptibility to the mother's bones. Inadequate adjustment in the mother will cause more decalcification in the skeleton of the mother's bones, especially in the third trimester, when calcium transfer increases dramatically. Therefore, the concentration of vitamin $D$ must be increased during pregnancy. Changes in vitamin $D$, together with increased efficiency of intestinal calcium absorption, doubles its capacity to help mothers accommodate the fetus's need for calcium $(17,18)$.

The patient in this case report was given $2 \times 500 \mathrm{mg}$ of calcium supplementation and $3 \times 400 \mathrm{mg}$ of vitamin D cholecalciferol. The choice of therapy was based on consistent evidence from RCT studies, and a meta-analysis that vitamin D supplementation combined with calcium reduces the risk of falls and fractures. Active vitamin $D$ is not preferred because of an increased risk of hypercalcemia. Additional calcium supplements can be considered if the daily calcium intake is below $700 \mathrm{mg} /$ day, with a maximum daily supplement dose of 1000 to 1200 $\mathrm{mg}$. For calcium supplementation combined with vitamin $D$, the recommended minimum dose of vitamin D is $800 \mathrm{IU}$ $(16,19,20)$.

Bergman et al., also support the use of cholecalciferol 800 IU/day to reduce the incidence of non-vertebral and hip osteoporotic fractures. In the study, cholecalciferol with calcium provided better benefits compared to calcium alone. Vitamin $D$ supplementation was given to achieve or maintain the $25(\mathrm{OH}) \mathrm{D}$ level of at least $50 \mathrm{nmol} / \mathrm{L}$ with a better target $>75 \mathrm{nmol} / \mathrm{L}$ in all patients. A systematic review by Cochrane, the safety of vitamin $D$ supplementation, or in combination with calcium or other vitamins and minerals in pregnant women shows that there are no studies reporting eclampsia, and only one study ( $n=400$ women) reports pre-eclampsia in mothers. Pregnant women who receive vitamin D supplementation are less likely to have babies with a birth weight below 2500 g compared to women who do not receive the treatment (20).

The Royal College of Obstetricians and Gynecologists (RCOG) also recommends for high-risk women (women who have increased skin pigmentation, reduced sun exposure, and obesity) to get vitamin D supplementation of at least 800 units/day that can be combined with calcium. A study showed that dosages of cholecalciferol up to 4,000 iu per day are safe in pregnant women and are effective even though high doses of vitamin $D(300,000$ $500,000 \mathrm{iu}$ ) is not recommended in pregnancy (17).

In this case, the patient also experienced thrombocytopenia with clinical symptoms of gum bleeding. Thrombocytopenia puts the mother and fetus at a greater risk of bleeding, especially if the platelet levels are less than $20,000 / \mu \mathrm{L}(18,21)$. Thrombocytopenia, as one of the primary manifestations of ITP in SLE, is found in 10.9-17.9\% of SLE patients with high-dose corticosteroids as the first-line therapy. In this disorder, antiplatelet autoantibodies are found in $60 \%$ of SLE patients who are mostly IgG (60\%). Antigens from antiplatelet antibodies include glycoprotein la/Ila (Gpla/Ila), glycoprotein Ilb/IIla (Gpllb/IIla), glycoprotein membrane (allaß3integrin), and glycoprotein $\mathrm{Ilb} / \mathrm{Illa}$. Other causes of autoimmunemediated thrombocytopenia are antiphospholipid antibodies, antibodies to thrombopoietin and its receptors, and genetics (2). The specific therapy for SLE immune thrombocytopenia is similar to Primary ITP. In pregnancy, steroids or IVIG are recommended before 36 weeks of pregnancy if the platelet count is under $30.000 / \mu \mathrm{L}$, the patient is symptomatic, or an invasive procedure is considered. When approaching the delivery, the goal of therapy is to maintain platelet counts above $50.000 / \mu \mathrm{L}$. Prednisone $1 \mathrm{mg} / \mathrm{kgBW}$ could be used for treatment during pregnancy with a visible therapeutic response within 2-14 days, and Azathioprine can be given in pregnancy at a dose of $1.5-2 \mathrm{mg} / \mathrm{kg} /$ day (maximum 150 $\mathrm{mg} /$ day). IVIG can be considered when first-line therapy fails, or there is life-threatening bleeding, and ongoing infection occurs. Intravenous immunoglobulin at a dose of $1 \mathrm{~g} / \mathrm{kg}$ has a relatively fast therapeutic response (within 1-3 days). IVIG can be given without corticosteroids (22).

The most common maternal complications of thrombocytopenia in pregnancy are bleeding, such as antepartum hemorrhage, intrapartum hemorrhage, and post-partum hemorrhage, whereas complications in neonates depend on the underlying disease. In patient management, the patient was given a TC transfusion 1 pack/day in order to reduce the risk of bleeding and avoid the formation of anti-thrombocyte antibodies that often occurred if the patient was frequently given transfusions. IgG anti thrombocyte antibodies circulate in the blood circulation and have the ability to cross the placental blood barrier that could cause thrombocytopenia in the fetus that manifests purpura, ecchymosis, melena, or intracranial hemorrhage in the neonatal period (21).

Considering the risk of alloimmunization in patients receiving repeated platelet transfusions, it is important to know the transfusion response and the relationship of antibodies formed to the given platelet transfusion response. A study by Lubis et al., at RSCM showed that there was a relationship between HLA antibody class 1 with platelet transfusion response. Patients with positive class 1 HLA antibodies were a risk of experiencing 11.4 times of transfusion failure (Adjusted PR 11.4; 95\% Cl 2.219-58.557; $p=0.004$ ) (23).Data from previous studies indicate that there are $24-44 \%$ of TC transfusion failures in achieving satisfactory responses. This can be caused by non-immunological factors (63-67\%) that cause a decrease in platelet survival, such as sepsis, hepatosplenomegaly, massive bleeding, disseminated intravascular coagulation, 
or administration of certain drugs. Other causes are immunological factors (18-25\%) that cause platelet destruction from transfusion through antibody mediation due to alloimmunization of HLA, antigens in white blood cells and platelets, or both. The incidence of alloimmunization is higher in patients with a history of pregnancy than in the group without a history of pregnancy or transfusion. Antibodies against HLA class 1 were detected as much as $30 \%$ in a history of three times of pregnancy or more. This can be due to the existence of memory cells that can be activated by cells or cell fragments with HLA class 1.

The transfusion process stimulates the mother's immune system during pregnancy. This might explain the tendency for higher HLA antibodies in patients with a history of pregnancy. Antibodies to platelet specific antigens (human platelet antigens/HPA) have not been detected much, but it is known that $10 \%$ of women with HPA-1b are immunized with HPA-1a antigens during pregnancy. Based on several prospective studies, alloimmunization occurs on more than three times transfusions, whereas in other studies, it occurs on transfusions that are more than seven times. A study by Lubis et al., showed only 3 out of 36 (8.3\%) transfusions using leukocyte depleted platelet concentrates, most of the transfusion used concentrated platelets (non-leukocyte depleted). The use of leukocyte depleted transfusions reduces the incidence of HLA alloimmunization. This is due to decreased antigen presentation by donor leukocytes and reduced amount of

\section{REFERENCES}

1. Buckley L, Guyatt G, Fink HA, et al. 2017 American College of Rheumatology Guideline for the Prevention and Treatment of GlucocorticoidInduced Osteoporosis. Arthritis \& Rheumatology. 2017; 69(8): 1521-1537.

2. Perhimpunan Reumatologi Indonesia. Rekomendasi Perhimpunan Reumatologi Indonesia: Diagnosis dan Pengelolaan Lupus Eritematosus Sistemik. Jakarta: Perhimpunan Reumatologi Indonesia; 2019.

3. Yun KY, Han SE, Kim SC, Joo JK, and Lee KS. Pregnancy-Related Osteoporosis and Spinal Fractures. Obstetrics \& Gynecology Science. 2017; 60(1): 133-137.

4. Levy S, Fayez I, Taguchi, N Han, et al. Pregnancy Outcome Following in Utero Exposure to Bisphosphonates. Bone. 2009; 44(3): 428-430.

5. Djokanovic N, Klieger-Grossmann C, and Koren G. Does Treatment with Bisphosphonates Endanger the Human Pregnancy? Journal of Obstetrics and Gynaecology Canada. 2008; 30(12): 1146-1148.

6. Hong $\mathrm{N}$ and Yumie Rhee. Comparison of Efficacy of Pharmacologic Treatments in Pregnancy and Lactation-Associated Osteoporosis. Clinical Reviews in Bone and Mineral Metabolism. 2019; 17: 86-93.

7. Sarıkaya S, Özdolap Ş, Açıkgöz G, and Erdem CZ. Pregnancy-Associated Osteoporosis with Vertebral Fractures and Scoliosis. Joint Bone Spine. 2004; 71(1): 84-85.

8. Allali F, Guedirra N, and Hajjaj-Hassouni N. A Case of Post-Pregnancy Osteoporosis-Related Spinal
HLA class 1 antigens. Data showed that about 50\% of patients with a history of pregnancy, who are transfused with non-leukocyte depleted, formed antibodies against HLA. The TRAP study shows the benefits of using leukocyte depleted transfusion in patients with a history of pregnancy. Reducing donor exposure by using single donor apheresis is considered to slow the incidence of alloimmunization (23).

There is no official guideline in the treatment of pregnancy with osteoporosis. The treatment options are limited to reported cases. The termination of breastfeeding is recommended in most cases. Other options include calcium and vitamin D supplementation with a recommended daily calcium dose of 1000 to 1200 $\mathrm{mg}$, and the recommended vitamin $\mathrm{D}$ is cholecalciferol with a minimum dose of $800 \mathrm{IU} /$ day. Bisphosphonates and teriparatide can be given to treat post-partum vertebral fractures. Azathioprine with a minimum dose of $<1.5-2 \mathrm{mg} / \mathrm{kg} /$ day can be given to SLE patients with ITP who are pregnant. The higher risk of platelet alloimmunization in pregnancy indicates the need for caution of platelet transfusion in pregnancy or the use of apheresis or leukocyte depleted platelet transfusion in patients with pregnancy to avoid the risk of alloimmunization.

\section{CONFLICT OF INTEREST}

The authors declare that they have no conflict of interest.

Fractures in Association with Ankylosing Spondylitis. Clinical Rheumatology. 2005; 24(4): 435-436.

9. Grizzo FMF, da Silva Martins J, Pinheiro MM, Jorgetti V, Carvalho MDB, and Pelloso SM. Pregnancy and Lactation-Associated Osteoporosis: Bone Histomorphometric Analysis and Response to Treatment with Zoledronic Acid. Calcified Tissue International. 2015; 97(4): 421-425.

10. Zhang M, Chen P, Li B, Du J, Pan T, and Chen J. Approach to the Patient with Pregnancy and Lactation-Associated Osteoporosis: A Case Report and a Review of the Literature. Medicine (Baltimore). 2017; 96(46): e8671.

11. Polat SB, Evranos B, Aydin C, Cuhaci N, Ersoy R, and Cakir B. Treatment of Severe Pregnancy and Lactation-Related Osteoporosis with Teriparatide: Case Report and Review of the Literature. Gynecological Endocrinology. 2015; 31(7): 522-525.

12. Ijuin A, Yoshikata H, Asano R, Tsuburai T, Kikuchi R, and Sakakibara H. Teriparatide And Denosumab Treatment For Pregnancy And Lactation-Associated Osteoporosis With Multiple Vertebral Fractures: A Case Study. Taiwanese Jjournal of Obstetrics \& Gynecology. 2017; 56(6): 863-866.

13. Winarno A, Kyvernitakis I, and Hadji P. Successful Treatment of 1-34 Parathyroid Hormone (PTH) after Failure of Bisphosphonate Therapy in a Complex Case of Pregnancy Associated Osteoporosis and Multiple Fractures. Zeitschrift Für Geburtshilfe Und Neonatologie. 2014; 218(4): 171-173.

14. Pickar JH, MacNeil T, and Ohleth K. SERMs: Progress and Future Perspectives. Maturitas. 2010; 67(2): 129- 
138.

15. McClung MR. Romosozumab for the Treatment of Osteoporosis. Osteoporosis and Sarcopenia. 2018; 4(1); 11-15.

16. World Health Organization. Guideline: Vitamin $D$ Supplementation in Pregnant Women. Geneva: World Health Organization; 2012.

17. Royal College of Obstetricians and Gynaecologists. Vitamin $D$ in Pregnancy. London: Scientific Impact Paper No. 43 June 2014; 2014; p. 1-11

18. Sanz-Salvador L, Ángel García-Pérez M, Tarín JJ, and Cano A. Bone Metabolic Changes during Pregnancy: A Period of Vulnerability to Osteoporosis and Fracture. European Journal of Endocrinology. 2015; 172(2): R53-R65.

19. Caprio $M$, Infante $M$, Calanchini $M$, Mammi $C$, and Fabbri A. Vitamin D: Not Just the Bone. Evidence for Beneficial Pleiotropic Extraskeletal Effects. Eating and Weight Disorder. 2017; 22(1): 27-41.

20. De-Regil LM, Palacios C, Ansary A, Kulier R, and PeñaRosas JP. Vitamin D Supplementation for Women during Pregnancy. The Cochrane Database of Systematic Reviews. 2013; 2: 1-55.

21. Saputra BA, Rodiani, and Puspita RD. Kehamilan dengan Trombositopenia. Medula. 2018; 8(1): 94101.

22. Ciobanu AM, Colibaba S, Cimpoca B, Peltecu G, and Panaitescu AM. Thrombocytopenia in Pregnancy. MAEDICA-Journal of Clinical Medicine. 2016; 11(1): 55-60.

23. Lubis AM, Sudoyo AW, Effendy S, TB Djumhana, and Harimurti K. Hubungan Antibodi Anti Trombosit terhadap Respon Transfusi Trombosit pada Pasien Hemato-Onkologi yang Mendapatkan Multitransfusi Trombosit di RS Dr. Cipto Mangunkusomo. Jurnal Penyakit Dalam Indonesia. 2015; 2(4): 1-8 